\title{
Phenotypic plasticity in the green algae Desmodesmus and Scenedesmus with special reference to the induction of defensive morphology
}

\author{
M. Lürling
}

Dept. Environmental Sciences, Aquatic Ecology and Water Quality Management Group, Wageningen University, P.O. Box 8080, 6700 DD Wageningen, The Netherlands. E-mail : miquel.lurling@wur.nl

\begin{abstract}
Organisms belonging to the green algal genera Desmodesmus and Scenedesmus are characterized by a high degree of flexibility allowing them to be true cosmopolitans and to withstand harsh conditions. The environmental conditions determine which phenotypes are being produced and one of the most dangerous situations for the algae is when the organisms are confronted with strong grazing pressure from numerous zooplankton organisms. An overview is given of several aspect of an induced defense in many non-spiny Scenedesmus and some spiny Desmodesmus that may form typical protective eight-celled colonies to avoid mortality from numerous grazers. The morphological response does seem to be linked with a herbivorous zooplankton chemical cue, rather than to a more general animal excretory product. The grazing activity of small sized grazers is reduced, but not of large Daphnia. However, arguments are given why grazing protection of colonial Scenedesmus is probably more efficient under natural than under carbon/light limited laboratory conditions. Finally, a life-history cycle of Desmodesmus and Scenedesmus is presented in which biological aspects such as the anti-grazer response and sexual reproduction are being included.
\end{abstract}

Keywords : grazing resistance, induced defense, infochemical, kairomones, life cycle.

\section{Introduction}

The freshwater green algal genera Desmodesmus and Scenedesmus are among the commonest genera of freshwater algae. They can be found in freshwater bodies all around the world, and even in the soil (Trainor 1998). Their cosmopolite appearance illustrates the wide range of environmental conditions those organisms can tolerate and explains why they were among the first algae established in laboratory cultures ; they are easy to grow and handle (Trainor 1998). Already 175 years ago Scenedesmus was studied and diagrams of four-celled colonies were recorded, but placed in the diatom genus Achnantes (Turpin 1828). Meyen (1829) was the first who used the generic name Scenedesmus and hence the genus is called Scenedesmus Meyen. After a century, the genus was divided in four subgenera, Clathrodesmus, Desmodesmus, Euscenedesmus and Rhynchodesmus (Chodat 1926). Fifty years after the description by Chodat (1926), a new subdivision for the genus Scenedesmus Meyen was presented with the subgenera Acutodesmus, Desmodesmus and Scenedesmus (Hegewald 1978). However, Trainor et al. (1976) stated «We feel that when we talk about Scenedesmus, we are talking about 2 distinct groups of organisms, two genera». They characterized the two groups as the non-spiny and the spiny group (Trainor et al. 1976). Attempts to reassess the taxonomy of Scenedesmus by biochemical and physiological properties failed and molecular techniques such as DNA/DNA hybridization and nucleotide sequence analysis were introduced to assist the reclassification of Scenedesmus (Kessler et al. 1997). Sequence analysis of the 18S-rDNA gene clearly supported the designation of just two subgenera, Desmodesmus and Scenedesmus. The existing separation in the two subgenera Acutodesmus and Scenedesmus (Hegewald 1978) was not supported by this analysis and combined into one subgenus Scenedesmus (Kessler et al. 1997). Subsequent sequence analysis of the more variable internal transcribed spacer 
2 (ITS-2) region was used to further clarify the taxonomy of Scenedesmus (An et al. 1999). The phylogeny based on 18S-rDNA-sequence analysis was confirmed, and once more the subgenus Acutodesmus could not be supported. Furthermore, the large genetic distance between the two subgenera and their clear distinct cell wall ultrastructure supported retention of the Scenedesmus Meyen for non-spiny organisms and formation of a genus Desmodesmus (Chodat) An, Friedl et Hegewald for those which could bear spines (An et al. 1999, Hegewald 2000). Phylogenetic analysis based on a revised secondary structure model for ITS-2 confirmed the division of the old genus Scenedesmus into the new genera Scenedesmus and Desmodesmus (Van Hannen et al. 2002).

Members of the old genus Scenedesmus are firmly anchored as standard test organisms and widely used in current research as highlighted by 1135 studies found in a literature survey using Biological Abstracts and Current Contents (Winspirs 4.0) over the period January 1989 to February 2003 with the keyword Scenedesmus. The survey for the most common species yielded 548 hits for non-spiny species and 435 ones for spiny organisms. The five most frequently encountered species in each new genus are given in Table 1. Delimiting the search to publication year 2002 and the first two months of 2003 revealed 53 studies for Scenedesmus and 4 for Desmodesmus (in total from 1989 to 2003 the keyword Desmodesmus yielded 10 studies). The relatively low number of studies with Desmodesmus can be explained from investigators still being unaware of the division of the old genus Scenedesmus into the new genera Scenedesmus and Desmodesmus. Rerunning the limited search over 2002/2003 with the five most frequently encountered spiny species, but with the old generic name, yielded 19 studies (i.e. 11 times Scenedesmus quadricauda; 5 times $S$. subspicatus ; one hit for $S$. armatus ; none for $S$. communis, and two for $S$. abundans).

\section{Reproduction}

The most common way, in which Scenedesmaceae reproduce, is asexually by the formation of autospores. Inside the parental cell wall the mother cell undergoes from 1 to 4 successive divisions into 2 to 16 daughter cells (Trainor et al. 1976, Trainor 1998).

The daughter cells may be released as a new colony varying in number of cells per colony by a simple unrolling (Smith 1914). However, although Desmodesmus and Scenedesmus are usually thought of as fourcelled colonies, many species may produce unicells as well (Chodat 1926, Egan \& Trainor 1990, Fott 1968, Swale 1967, Trainor \& Roskosky 1967, Trainor 1998, Van den Hoek et al. 1995). In spiny Desmodesmus, unicells may result when the daughter cells fail to join and additional spines may appear on each cell (Trainor \& Rowland 1968). Unicells may also be the product of colony disintegration; in the unrolling of the new coenobe from the mother cell seperation of cells may occur between different cells (Smith 1914). In the nonspiny Scenedesmus this seems the normal pathway for unicell production (Kylin \& Das 1967, Nilshammar \& Walles 1974). Far less observed, but certainly not absent in Scenedesmus and Desmodesmus is sexual reproduction. Motile cells were first noted in Scenedesmus obliquus, both in the laboratory and in cultures incubated in nature (Trainor 1963, 1965, Trainor \& Burg 1965a). Trainor and Burg (1965b) observed motility in

Table 1. Results of a literature survey using Biological Abstracts and Current Contents (Winspirs 4.0) over the period January 1989 to February 2003 with the keyword Scenedesmus. The spiny organisms are separated according to the new nomenclatoric transfer into the revised genus Desmodesmus (sensu Hegewald 2000). The five most frequently encountered species in each new genus are given.

\begin{tabular}{cccc}
\hline \multicolumn{2}{c}{ Scenedesmus (non-spiny) } & \multicolumn{2}{c}{ Desmodesmus (spiny) } \\
\hline species & \# hits & species & \# hits \\
\hline S. obliquus & 287 & D. quadricauda & 228 \\
S. acutus & 149 & D. subspicatus & 76 \\
S. acuminatus & 28 & D. armatus & 35 \\
S. bijugatus & 18 & D. communis & 13 \\
S. dimorphus & 13 & D. abundans & 12 \\
\hline \hline
\end{tabular}


two $S$. obliquus and three $S$. dimorphus strains. Almost thirty years after the first recording of motile Scenedesmus, the finding was confirmed in a sample of S. obliquus from an outdoor unit (Lukavský 1991, Lukavský \& Cepák 1998) and in the laboratory in S. acutus exposed to hexavalent Chromium (Corradi et al. 1995). Where initial studies failed to induce gametogenesis in spiny organisms (Trainor \& Burg 1965, Cain \& Trainor 1976), over a decade ago gamete production in Desmodesmus armatus has been observed (Egan \& Trainor 1989a, Trainor 1993a). Mixing gametes from two different $S$. obliquus strains (EL19 and WH50) resulted in immediate clumping of gametes, with 5 to 10 cells per clump (Trainor 1998). Pairs of gametes were affixed with their flagella, and after breaking away from the clump fused rapidly into a quadriflagellate zoospore, which grew into a large spherical zygote. The organisms released from the zygote appeared always unicells (Trainor 1998).

\section{Phenotypic plasticity}

For long the old genus Scenedesmus Meyen was thought to include all colonial green algae having flat colonies that consist of two, four, eight or 16 fusiform or oblong cells linearly arranged along their long axes. The organisms with fusiformed cells lack spines, whereas the organisms with oblong cells may have various arrangements of spines or be spineless (Trainor et al. 1976) and are now divided in two distinct genera (An et al. 1999, Hegewald 2000). Once believed to be stable ( $c f$. Smith 1916), morphological characters were used to describe each new morphological form as a separate species or variety (Uherkovicz 1966, Hegewald \& Silva 1988). After decades, this approach led to an impressive «annotated catalogue of Scenedesmus and nomenclaturally related genera» comprising over 1300 species and intraspecific second-order taxa (Hegewald \& Silva 1988). However, intensive efforts by Frank Trainor and co-workers challenged the assumption that each different morph was equivalent to a different genotype and they revealed detailed information on morphological variability in several strains of «Scenedesmus» (Trainor et al. 1976, Trainor 1998). It turned out that cell size, cell arrangement ; spine number and position as well as other wall ornamentation were not as stable in several strains investigated as had been assumed (Trainor 1998). This ability of a single genotype to produce one or more alternative form of morphology in response to environmental conditions is termed phenotypic plasticity (West-Eberhard 1989).

The environmental conditions not only determine which phenotypes will be produced, but also provide the arena where different morphologies experience different growth and survival and thus which are subjected to selection (West-Eberhard 1989). Competition and predation are considered the major selective forces responsible for organizing and structuring communities. They are the most important biotic factors affecting populations of primary producers and consumers and they commonly interact with one another (Gurevitch et al. 2000). Whereas predation will exert a strong effect on survival, competition will strongly act upon growth and reproduction. In general, predation is blatantly more lethal than resource competition, but in order to grow and reproduce survival and resource acquisition are essential to every organism. Many environmental conditions act upon growth, development and mortality of Scenedesmus (Fig. 1). Of particular interest is the fact that zooplankton excreta can trigger the formation of colonies, which could be interpreted as an induced defense (Hessen \& Van Donk 1993, Lampert et al. 1994).

\section{Grazer-induced morphological changes in Des- modesmus and Scenedesmus}

\section{The algae}

A first report on Scenedesmus colony formation in the presence of herbivorous zooplankton was reported in Russia over twenty years ago (Mikheeva \& Kruchkova 1980). Hessen and Van Donk (1993) discovered the involvement of a chemical cue released from the zooplankton in stimulation of colonies. The addition of filtered medium from a Daphnia culture (2\% v/v) to unicellular Desmodesmus subspicatus populations resulted within two days in populations dominated by colonies, while the controls remained unicellular. An increase in the mean number of cells per colony was observed from 1.4 in the controls to 4.9 in the Daphnia treatments. Some two- and four-celled colonies were formed, but the majority of the colonies were eightcelled (Fig. 2). The dimensions increased from $8 \times 5 \mu \mathrm{m}$ in unicells to $40 \times 6 \mu \mathrm{m}$ in eight-celled colonies, and when the proportion of eight-celled colonies was high grazing of a $1.75 \mathrm{~mm}$ Daphnia was reduced by $75 \%$ reflecting an increased grazing resistance of the colonies (Hessen \& Van Donk 1993).

A year later Lampert and co-workers (1994) confirmed the phenomenon using a non-spiny organism, $S$. obliquus (formerly known as $S$. acutus sensu Van Hannen et al, 2000). As in D. subspicatus a dramatic increase was observed in the number of colonies when initially unicellular cultures were exposed for $48 \mathrm{~h}$ to $4 \%$ (v/v) filtered medium in which Daphnia had been grown. The proportion of eight-celled colonies showed 


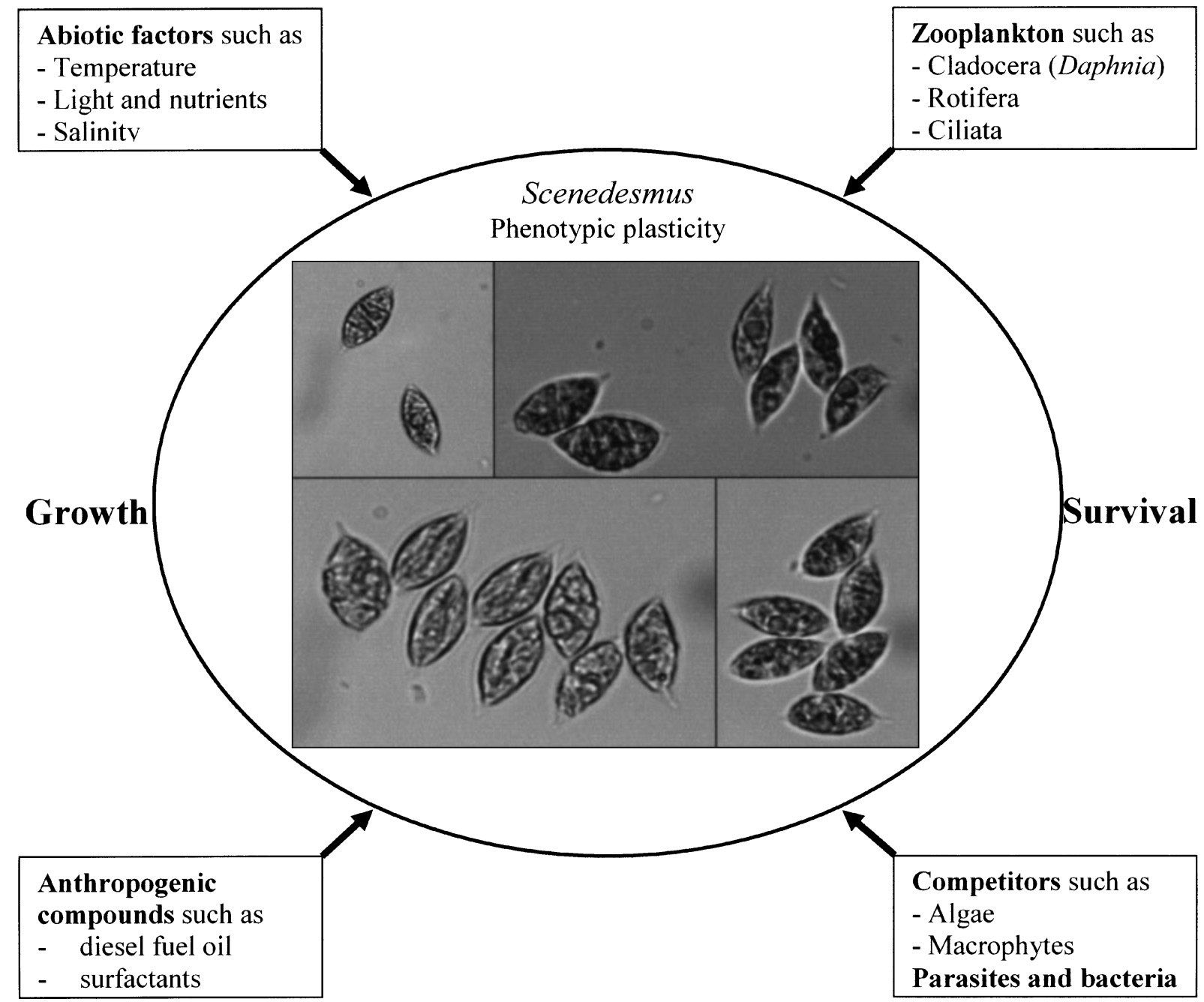

Fig. 1. Different morphologies of Scenedesmus obliquus (presented as unicells, 2-, 4-, 6-, and 8-celled colonies) as an example of phenotypic plasticity influenced by various environmental factors (both biotic and abiotic) that consequently will affect growth and/or survival.

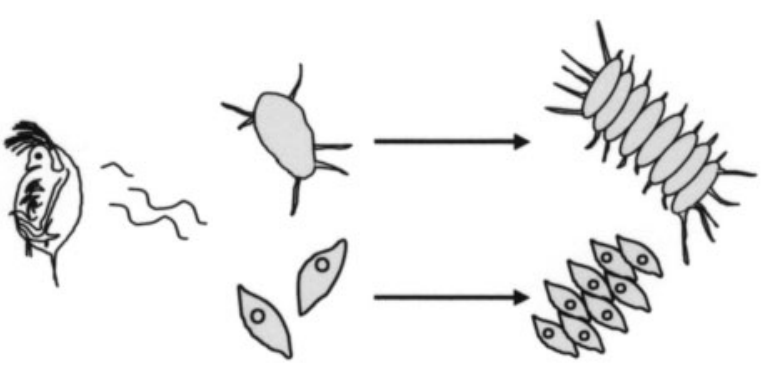

Fig. 2. Daphnia-induced unicell-colony transformation in Desmodesmus subspicatus (drawn after Hessen \& Van Donk 1993) and Scenedesmus obliquus. a 5-fold increase making up almost $50 \%$ of the population (Lampert et al. 1994). Active growth is a precondition for the formation of colonies (Lampert et al. 1994) meaning that the induced colony formation is the result of the asexual reproductive process of autosporulation and not of lumping of individual cells.

When $S$. obliquus was grown in the absence (control) or presence of $10 \%(\mathrm{v} / \mathrm{v})$ filtrate from a Daphnia culture (Daphnia water treatments), growth was unaffected during the first days, but Scenedesmus morphology was changed drastically in the treatment populations (Fig. 3). In the treatment populations a ra- 


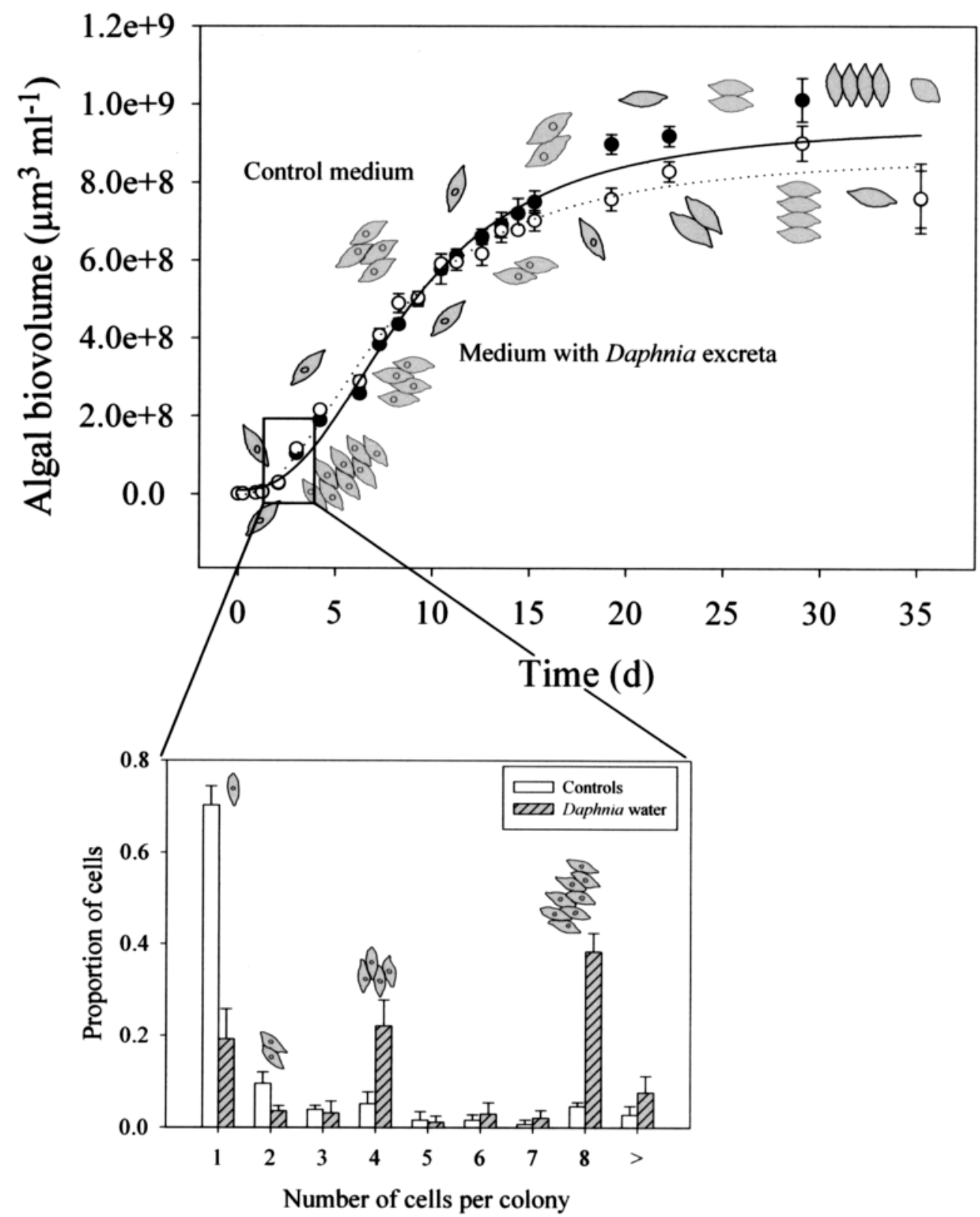

Fig. 3. Growth curves for Scenedesmus obliquus grown for 35 days in the absence (Control medium) and presence of $10 \%$ (v/v) filtered medium from a Daphnia culture (Medium with Daphnia excreta), including the composition of the populations after 3 days. Error bars represent one standard deviation ( $N=4$; data from Lürling, 1998). 
pid formation of 4-celled coenobia (47 \% of population on day 2 ) and 8 -celled coenobia (38\% on day 3 ) could be observed followed by a subsequent recovery of unicell abundance (Fig. 3). The control populations were dominated by unicells which made-up more than $70 \%$ of the population. From 7-14 days, the dominance of unicells in the control populations gradually decreased to $38 \%$ on day 11 , while the proportion of 4-celled coenobia concomitantly increased to $34 \%$ on day 11. Meanwhile, after 15 days, as cultures reached carrying capacity, population composition seemed to stabilize and was more or less comparable between control and treatment populations (Fig. 3). Reduced concentration of the inducing chemicals and increased population size resulted in gradually lower exposure of cells to these chemicals. Inactivation may be caused by absorption and incorporation of the inducing chemicals in the algal cells (Lürling et al. 2000), and by bacterial degradation as the strain that had been used ( $S$. obliquus MPI) was not completely free of bacteria. The colony inducing ability disappeared within two days from lake water when bacteria were present, but remained active without bacteria (Lürling \& Van Donk 1997a), which in fact has also been observed for laboratory water from a Daphnia culture (Van Holthoon pers. comm.). Degradation of the chemical cue limits the persistence of the colony-inducing chemicals and contributes to the reliability of the cue, as it ensures that the concentration of the infochemical reflects the actual risk of predation.

Meanwhile several strains of Desmodesmus (22) and Scenedesmus (18) have been subjected to examination of possible morphological changes induced after exposure to filtered water from Daphnia cultures (Table 2). Of all 22 Desmodesmus strains tested, inducible colony formation was observed in four strains, of which in two only occasionally and in a third (UTEX 614) only in the presence of a rotifer (Table 2 ; Fig. 4). In Scenedesmus, 13 out of 18 strains showed inducible colony formation, 3 only occasionally, and in two strains no colony induction was observed (Table 2 ; Fig. 4). Hen$c e$, these data suggest that grazer-induced colony formation is more widespread among the non-spiny Scenedesmus than among spiny Desmodesmus.

\section{The grazers}

The release of chemicals triggering the unicell-colony transformation or promoting the formation of eightcelled colonies is certainly not restricted to large-bodied cladocera, such as Daphnia magna which had been used in the initial experiments (Hessen \& Van Donk 1993, Lampert et al. 1994). Franck (1995) already showed that the rotifer Brachionus could induce colonies in S. obliquus too, which was confirmed by Lurling and Van Donk (1997a). The latter also found colony induction in $S$. obliquus (formerly $S$. acutus) expo-

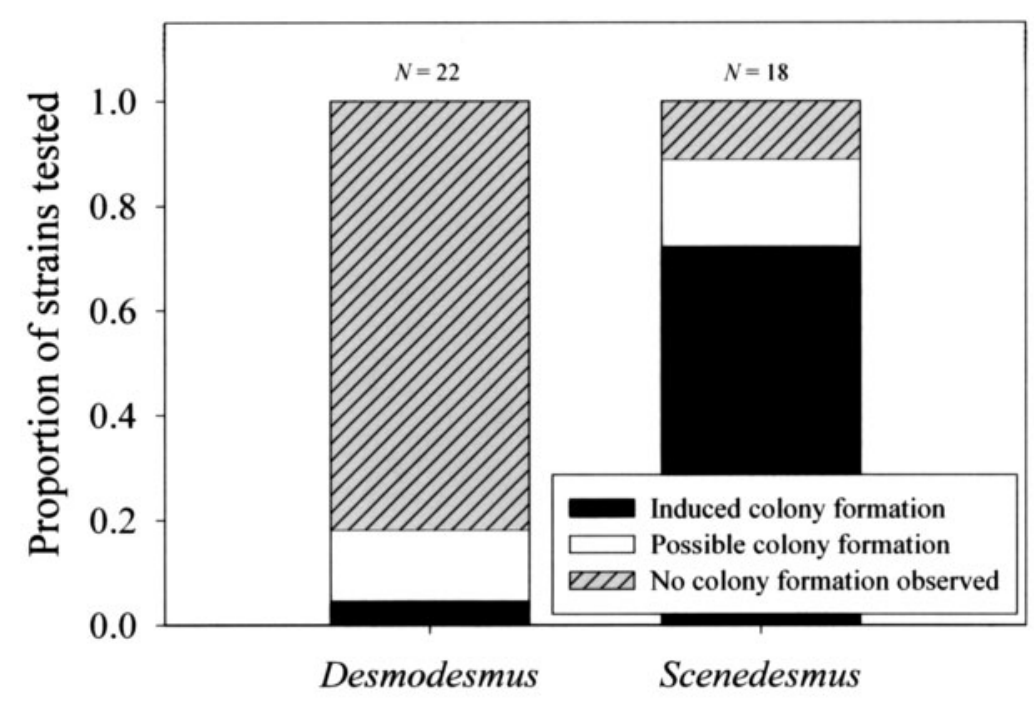

Fig. 4. Proportion of Desmodesmus and Scenedesmus strains tested for grazer-induced colony formation. The black areas indicate induced colony formation, the gray/shaded area represent no-observed-colony-formation and possible colony formation is given by the white areas. 
Table 2. Desmodesmus and Scenedesmus strains tested for inducible colony formation.

\begin{tabular}{|c|c|c|}
\hline Strain & Culture collection & $\begin{array}{c}\text { Colony } \\
\text { formation }\end{array}$ \\
\hline \multicolumn{3}{|l|}{ Scenedesmus } \\
\hline S: acuminatus NIVA-CHL58 & Norwegian Institute for Water Research & Yes $^{11}$ \\
\hline S. acuminatus UTEX 415 & University of Texas, USA & No $*$ \\
\hline S. acutus UTCC-T7 & University of Toronto, Canada & $\mathrm{No}^{4)}$ \\
\hline S. acutus UTCC-T10 & University of Toronto, Canada & $\pm^{4,5)}$ \\
\hline S. basiliensis UTEX 79 & University of Texas, USA & Yes * \\
\hline S. falcatus MPI & Max-Planck-Institute Limnology, Germany & Yes $^{4,5)}$ \\
\hline S. obliquus MPI & Max-Planck-Institute Limnology, Germany & Yes $^{3)}$ \\
\hline S. obliquus SAG276/1 & University of Göttingen, Germany & $\pm 4,6)$ \\
\hline S. obliquus SAG276/3a & University of Göttingen, Germany & Yes ${ }^{7)}$ \\
\hline S. obliquus UTEX 72 & University of Texas, USA & $\pm^{4,5)}$ \\
\hline S. obliquus UTEX 74 & University of Texas, USA & Yes $*$ \\
\hline S. obliquus UTEX 78 & University of Texas, USA & Yes ${ }^{6)}$ \\
\hline S. obliquus UTEX 393 & University of Texas, USA & Yes * \\
\hline S. obliquus UTEX 1450 & University of Texas, USA & Yes $\left.^{6}\right)$ \\
\hline S. obliquus UTEX 2630 & University of Texas, USA & Yes ${ }^{6)}$ \\
\hline S. obliquus NIVA-CHL6 & Norwegian Institute for Water Research & Yes $^{1,6)}$ \\
\hline S. obtusiusculus & University of Turku, Finland & $\mathrm{Yes}^{4)}$ \\
\hline S. sp.MV7 & Centre for Limnology, The Netherlands & Yes \\
\hline \multicolumn{3}{|l|}{ Desmodesmus } \\
\hline D. abundans UTEX 1358 & University of Texas. USA & No * \\
\hline D. armatus MPI & Max-Planck-Institute Limnology, Germany & $\mathrm{No}^{+}$ \\
\hline D. bicellularis CCAP276/14 & Culture Collection Algae \& Protozoa, UK & $\mathrm{No}^{*}$ \\
\hline D. ecornisUTEX LB 1359 & University of Texas, USA & No \\
\hline D. gutwinskii B3-15 & Obtained from Dr Fumie Kasai, Japan & $\mathrm{No}^{4)}$ \\
\hline D. gutwinskii B8-7 & Obtained from Dr Fumie Kasai, Japan & No ${ }^{4)}$ \\
\hline D. gutwinskii B8-27 & Obtained from Dr Fumie Kasai, Japan & $\mathrm{No}^{4)}$ \\
\hline D. pannonicus UTEX 77 & University of Texas, USA & No $*$ \\
\hline D. protuberans & University of Amsterdam. The Netherlands & Yes $^{4)}$ \\
\hline D. quadricauda $\mathrm{F} 11$ & Saskatchewan research Council, Canada & $\mathrm{No}^{5)}$ \\
\hline D. quadricaudaNIVA-CHL7 & Norwegian Institute for Water Research & No ${ }^{1,5)}$ \\
\hline D. quadricauda UTEX 76 & University of Texas, USA & $\mathrm{No}^{5)}$ \\
\hline D. quadricauda UTEX 614 & University of Texas, USA & \pm \\
\hline D. sp. MV3 & Centre for Limnology, The Netherlands & No $*$ \\
\hline D. $s p$. MV5 & Centre for Limnology, The Netherlands & $\mathrm{No}^{*}$ \\
\hline D. subspicatus CCAP276/20 & Culture Collection Algae \& Protozoa, UK & No * \\
\hline D. subspicatusNIVA-CHL55 & Norwegian Institute for Water Research & $\pm^{1,2,4)}$ \\
\hline D. subspicatus RWTH & University Aachen, Germany & No ${ }^{4)}$ \\
\hline D. subspicatus SAG53.80 & University of Göttingen, Germany & $\mathrm{No}^{4)}$ \\
\hline D. subspicatus SAG54.80 & University of Göttingen, Germany & No ${ }^{4)}$ \\
\hline D. subspicatus UTEX 2532 & University of Texas, USA & No ${ }^{4)}$ \\
\hline D. subspicatus UTEX 2594 & University of Texas, USA & $\pm^{4)}$ \\
\hline
\end{tabular}

Notes $:$ Yes $=$ colonies induced $;$ No $=$ no colony induction found $; \pm=$ possible colony induction $\left.{ }^{1}\right)$ $\begin{array}{lll}\text { Van Donk et al. (1999) } & \text { 2) Hessen \& Van Donk (1993) } & \text { 3) Lampert et al. (1994) }\end{array}$

4) Lürling (1999a) 5) Lürling \& Beekman (1999) 6) Lürling (1999b)

7) Von Elert \& Franck (1999) (\$) Unpublished data 
sed to filtrate from the cladocera Bosmina longirostris and Daphnia galeata as well as in filtrate from the copepod Eudiaptomus gracilis. Van Donk et al. (1999) listed 14 species that had been examined at that time for the ability to induce the formation of protective colonies in Scenedesmus. In the meantime more organisms have been investigated, including carnivorous cladocerans (Bythotrephes and Leptodora), fish (Leuciscus and Perca), a freshwater ciliate and some more cladocerans (Table 3). The results of these experiments are in favour of the hypothesis that Scenedesmus responds to a herbivorous zooplankton chemical cue, ra- ther than to a more general animal excretory product. Exposure to water-borne cues from herbivorous zooplankton stimulated the formation of protective colonies in Scenedesmus. However, when exposed to medium that had been inhabited by carnivorous cladocerans, ostracods or fish, no colony formation in Scenedesmus was observed (Table 3 ).

\section{Grazing resistance of colonies}

Hessen and Van Donk (1993) found up to $75 \%$ reduction in the grazing rate of a 1.75-mm Daphnia when the proportion of eight-celled colonies was high,

Table 3. Organisms tested for the ability to induce colonies in Scenedesmus.

\begin{tabular}{cccc}
\hline Organisms & $\begin{array}{c}\text { Colony } \\
\text { induction in } \\
\text { Scenedesmus }\end{array}$ & $\begin{array}{c}\text { Density } \\
\text { (ind. L }\end{array}$ & Reference \\
\hline $\begin{array}{c}\text { Cladocera } \\
\text { Bosmina longirostris }\end{array}$ & Yes & 100 & Lürling \& Van Donk 1997a \\
$\begin{array}{c}\text { Bythotrephes longimamus } \\
\text { Ceriodaphnia reticulata }\end{array}$ & No & 50 & Lürling submitted \\
Chydorus sphaericus & Yes & 10 & Lürling submitted \\
Daphnia cucullata & Yes & 50 & Van Donk et al. 1999 \\
Daphnia galeata & Yes & 50 & Van Donk et al. 1999 \\
Daphnia galeata hyalina & Yes & 2 & Van Donk et al. 1999 \\
Daphnia hyalina & Yes & 10 & Lürling submitted \\
Daphnia magna & Yes & 2 & Van Donk et al. 1999 al. 1999 \\
Daphnia pulex & Yes & 2 & Van Donk et al. 1999 \\
Daphnia pulicaria & Yes & 2 & Lürling submitted \\
Leptodora kindtii & No & 10 & Lürling submitted \\
Simocephalus vetulus & Yes & 2 & Lürling 1999a \\
Copepoda & & & \\
Cyclops agilis & No & 20 & Van Donk et al. 1999 \\
Eudiaptomus gracilis & Yes & 33 & Lürling \& Van Donk 1997a \\
Rotifera & & & \\
Brachionus calyciflorus & Yes & 100 & Lürling \& Van Donk 1997a \\
Keratella cochlearis & Yes & 100 & Van Donk et al. 1999 \\
Ostracoda & & & \\
Cypridopsis vidua & No & 20 & Van Donk et al. 1999 \\
Herpetocypris reptans & No & 20 & Van Donk et al. 1999 \\
Ciliata & & & \\
Spirostomum ambiguum & No & 500 & Lürling 1999a \\
Fish & & & \\
Leuciscus idus (ide) & No & 0.01 & Lürling submitted \\
Perca fluviatilis perch) & No & 0.02 & Lürling submitted \\
\hline
\end{tabular}

Note: Densities for positive responses represent minimum effective numbers (since $10 \% \mathrm{v} / \mathrm{v}$ filtrate is added animal incubation densities are tenfold higher than given), while for negative responses the maximum numbers tested are given. 


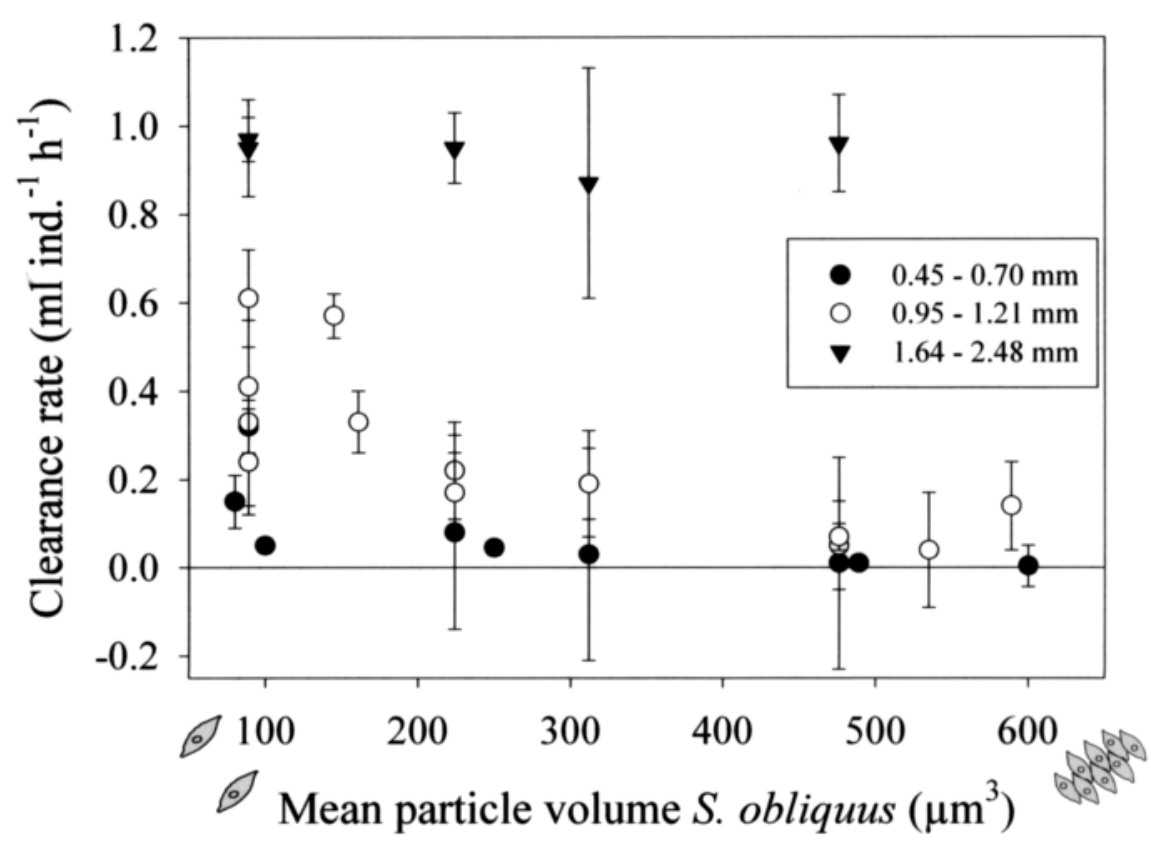

Fig. 5. Feeding of three different size classes of zooplankton grazers (Clearance rates in $\mathrm{ml}$ ind..$\left.^{-1} \mathrm{~h}^{-1}\right)$ on differently sized Scenedesmus obliquus expressed as mean particle volumes $\left(\mu \mathrm{m}^{3}\right)$.

reflecting an increased grazing resistance of the colonies. In contrast, Lampert et al. (1994) did not detect differences in the uptake of unicells and colonies of S. obliquus. In other studies small-sized Daphnia $(\sim 0.5-1.2 \mathrm{~mm})$ had depressed grazing rates on colonies compared to unicells, whereas large Daphnia $(\sim 1.6-2.5 \mathrm{~mm})$ had no problems ingesting the colonies (Fig. 5 ; data from Lürling \& Van Donk 1996, Lürling et al. 1997, Lürling 1999a, Van Donk et al. 1999). Several other small grazers, such as rotifers, Bosmina and Ceriodaphnia had lower grazing rates on colonies than on unicells (Lürling 1999a). Also protozoa may experience reduced grazing success when confronted with colonial Desmodesmus and Scenedesmus (Goulder 1972, Grover 1989). Hence, the colonial morphology is effective in reducing mortality through grazing. When fed colonial Scenedesmus, the growth rate of small sized Daphnia species was significantly reduced, but not of larger species (Lürling \& Van Donk 1996, Lürling et al. 1997).

Because large bodied cladocerans had no difficulties in harvesting the colonies, the protection against grazing for colonial Scenedesmus seems only effective against small grazers. Therefore, it has been postulated that colony formation as a defense against large zoo- plankters may be of little use (Wiltshire \& Lampert 1999). However, when dealing with highly plastic organisms one should be very careful with straightforward generalizations based on limited laboratory studies performed under similar, if not identical, environmental conditions. Desmodesmus and Scenedesmus are not only flexible pertaining to the number of cells per colony, but also in the size of the cells (Trainor 1998). The majority of laboratory studies have been performed under light/carbon limiting culturing conditions, which is caused by the often relatively high algal densities together with a low carbon content in most laboratory media. Growth media such as Z8 (Skulberg \& Skulberg 1990, Hessen \& Van Donk 1993), Chu (Lampert et al. 1994) and modified WC (Lürling 1998) are low in carbon content, whereas others even lack an (in)organic carbon source, such as Bristol's and medium 7 (Egan \& Trainor 1989b,c,d Ramos-Cárdenas \& de Lara-Isassi 1985) (see Table 4). Cultures may also be supplied with $\mathrm{CO}_{2}$ enriched air such as for 1/10 N8 medium (Hegewald 1982, 1989) and BBM (Belkinova \& Mladenov 2002), but still may give rise to relatively high algal densities. In contrast, in most natural waters inorganic carbon rarely appears to be a limiting nutrient (e.g. Schindler 1971, Goldman et al. 1972, 
Table 4. C, $\mathrm{N}$ and $\mathrm{P}\left(\mathrm{mg} \mathrm{l}^{-1}\right)$ concentrations in media used for culturing Scenedesmus spp. «—-» indicates that no carbon is added to the medium.

\begin{tabular}{lllll}
\hline Medium & $\mathrm{C}\left(\mathrm{mg} \cdot \mathrm{l}^{-1}\right)$ & $\mathrm{N}\left(\mathrm{mg} \cdot \mathrm{l}^{-1}\right)$ & $\mathrm{P}\left(\mathrm{mg} \cdot \mathrm{l}^{-1}\right)$ & Reference \\
\hline MPI & 21.4 & 7.0 & 1.2 & Sterner et al. (1993) \\
N8 & ---- & 140 & 190 & Holtmann \& Hegewald (1986) \\
Pr & ---- & 42 & 2 & Holtmann \& Hegewald (1986) \\
By & ---- & 33 & 7 & Holtmann \& Hegewald (1986) \\
Chu X & ---- & 7 & 2 & Holtmann \& Hegewald (1986) \\
Z10 & 24.0 & 7.7 & 0.73 & Schöler (pers. comm.) \\
Z8 20\% & 0.06 & 1.54 & 0.15 & Hessen \& Van Donk (1993) \\
Z4 & 24.0 & 19.2 & 1.82 & Schöler (pers. comm.) \\
Chu 12 & 2.9 & 7.26 & 0.72 & Lampert et al. (1994) \\
WC & 1.8 & 14.0 & 2.03 & Lürling (1998) \\
Bristol's & ---- & 41.2 & 53.1 & Egan \& Trainor (1989b,c,d) \\
Medium 7 & ---- & 0.33 & 0.005 & Egan \& Trainor (1989b,c,d) \\
Knop & ---- & 155.6 & 35.6 & Ramos-Cárdenas \& de Lara-Isassi (1985) \\
3.07 & ---- & 3.30 & 0.53 & Ramos-Cárdenas \& de Lara-Isassi (1985) \\
Medium K & ---- & 105 & 17.8 & Ramos-Cárdenas \& de Lara-Isassi (1985) \\
\hline \hline
\end{tabular}

Schindler et al. 1972), with average concentrations above $20 \mathrm{mg}$ inorganic-C per liter (Goldman et al. 1974).

Because carbon is a bulk element that makes up about $54 \%$ of the biomass in a Scenedesmus cell (Sterner 1993), in carbon limited culture conditions growth and morphology may be influenced and cells may become smaller than under carbon saturating conditions. For example, $S$. obliquus had dimensions of $15 \times 4 \mu \mathrm{m}$ under carbon limitation, but were 17.5 x $7 \mu \mathrm{m}$ under less limiting conditions (Lürling 1999a), while decreasing light intensities reduced the cell volume in $\mathrm{S}$. obliquus too (Senger \& Fleischhacker 1978). Literature data on the cell volume of the S. obliquus strain used in the studies on grazer-induced colony formation revealed considerable variation in the cell size. When cultured in high densities in chemostats a mean cell volume of $67 \mu \mathrm{m}^{3}$ was found (De Lange \& Van Donk 1997, Lampert et al. 1994, Lürling \& Van Donk 1996, 1997 a,b). However, much larger cell volumes of $\sim 200 \mu^{3}{ }^{3}$ in $S$. obliquus may not be uncommon when algal biomass is low (Lürling 1998, Lürling \& Van Donk 1999). Undoubtedly larger cell volume will affect the colony size, as cells are bigger. A highly significant correlation exists in S. obliquus between the mean particle volume and the mean number of cells per colony (Lampert et al. 1994, Lürling 1999a). Applying this relation to cells with a volume of $67 \mu^{3}$ yields an eight-celled colony of $\sim 300 \mu \mathrm{m}^{3}$, while cells with a volume of $200 \mu \mathrm{m}^{3}$ realize eight-celled colonies of $\sim 1000 \mathrm{um}^{3}$. Such variations in colony volumes will be reflected in colony dimensions. Indeed, using heavy inocula Lürling and Van Donk (1997a) found small eight-celled colonies in Scenedesmus with mean dimensions of 24 x $19 \mu \mathrm{m}$, while large eight-celled colonies with dimensions of 57 × $30 \mu \mathrm{m}$ were observed at low inoculum concentrations (Lürling 1998).

In the field, Holtmann and Hegewald (1986) found dimensions of $\sim 40 \times 30 \mu \mathrm{m}$ for the typical eight-celled $S$. pectinatus colonies. Dimensions of individual cells were considerably larger in S. pectinatus from the field, with mean cell length and width of 30.3 and $4.6 \mu \mathrm{m}$, respectively, than in the laboratory with cell length and width of 17.7 and $3.7 \mu \mathrm{m}$, respectively (Holtmann \& Hegewald 1986). Since bulk elements, such as carbon, vary little with growth conditions (Goldman et al. 1979) and may make up about $54 \%$ in Scenedesmus (Sterner 1993); cells of S. pectinatus in the field could have contained around $30 \%$ more carbon than in the laboratory. 
Uherkovich (1966) listed eight-celled S. acutus/obliquus colonies with dimensions of $\sim 35 \times 25 \mu \mathrm{m}$, Krienitz (1987) found eight-celled colonies up to $\sim 47 \times 26$ $\mu \mathrm{m}$ and Mladenov and Belkinova (1997) showed up to $\sim 40 \times 30 \mu \mathrm{m}$ sized eight-celled colonies of S. acuminatus and $S$. pectinatus. Eight-celled colonies of the latter species could even reach $\sim 53$ x $38 \mu \mathrm{m}$ (Mladenov \& Furnadzieva 1999). Canter-Lund and Lund (1995) list a picture of a field sample dominated by mainly eight-celled Desmodesmus up to $62 \mu \mathrm{m}$ in length. These large colonies could confront many grazers with ingestion problems ( $c f$. Burns 1968), because algae above $\sim 45 \mu \mathrm{m}$ cannot be ingested by even the largest Daphnia species (Porter 1977). Hence, due to bigger cell size in the field the grazing protection of colonial Scenedesmus is probably more efficient under natural than under carbon/light limited laboratory conditions.

It should be noted that the trait colony formation is only one of the potential anti-grazer defenses. Other potential defensive characteristics that may hamper ingestion are bristles and spines. Bristles of over $100 \mu \mathrm{m}$ long may form a net that may discourage even the largest grazers (Trainor \& Burg 1965c, Massalski et al.
1971, Trainor \& Egan 1988). Also the shorter and thicker spines may be effective against predators reducing for example Daphnia growth and reproduction (DeLange and Van Donk 1997). Defensive features that may give resistance to digestion include thick cell walls and mucilage (Horn 1981, Levitan 1987). Perhaps, the organisms may use several strategies to avoid predation, but if and how those characteristics will be affected by grazer-related chemical cues remains an open question.

\section{Morphological variability, buoyancy and unicells}

Desmodesmus colonies have higher sinking rates than unicells (Conway \& Trainor 1972). Similarily, induced-colonial Scenedesmus populations had higher sinking rates than unicellular ones (Lürling \& Van Donk 2000) and in general, sinking velocities increased with an increased colony size (Fig. 6). Perhaps the higher Scenedesmus sedimentation losses in the presence of zooplankton than in its absence (Visser et al. 1996) were a result of colony formation.

Unicells but also forms with bristles or spines and gametes are morphotypes with a greater resistance to sinking (Conway \& Trainor 1972, Trainor 1969, 1992,

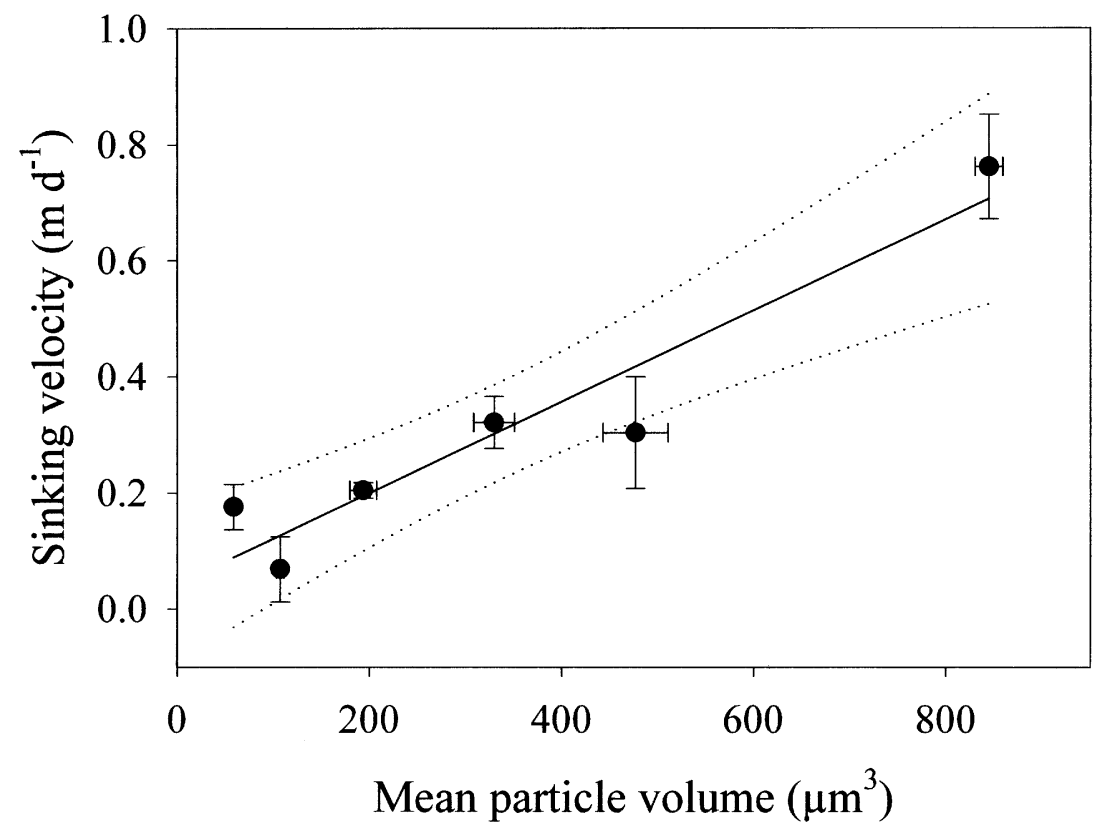

Fig. 6. Sinking velocities $\left(v_{\text {sed }}\right.$ in $\left.\mathrm{m} \mathrm{d}^{-1}\right)$ versus the mean particle volumes (MPV in $\left.\mu \mathrm{m}^{3}\right)$ in different Scenedesmus populations. The solid line represents linear regression $\left(v_{\mathrm{sed}}=0.043+7.852\right.$ x $10^{-4}$ x MPV ; $\left.r^{2}=0.906\right)$, the dotted lines the $95 \%$ confidence intervals and error bars indicate one standard deviation. 
Lukavský 1991). Hence, Scenedesmus unicells and small coenobia possessed a better buoyancy than large coenobia (Conway \& Trainor 1972) allowing them to maintain a position in the upper water layers where conditions are favorable to support good growth (Siver \& Trainor 1981). This means that the tax to be paid by Scenedesmus for the protective colonial morph is at least an enhanced chance of sinking out of the euphotic zone (Lürling \& Van Donk 2000). At first interpreted as a cost, inasmuch sinking out of the euphotic zone should imply lower growth, sinking could, however, also be interpreted as an escape in time. Scenedesmus is capable of surviving prolonged periods of darkness (Dehning \& Tilzer 1989), where colonies disintegrate and unicells may serve as inocula for subsequent blooms (Dehning \& Tilzer 1989, Egan \& Trainor $1989 \mathrm{~b}, \mathrm{~d})$. This led to a hypothetical seasonal life history of Desmodesmus/Scenedemus with unicells occurring in early spring (Egan \& Trainor 1989b,d). But why would unicells occur only in spring, especially since sufficient literature data exist on unicellular Scenedesmus under a wide range of nutrients and cell densities? In fact, in culture unicells may be very common (e.g. Hegewald 1982, Holtmann \& Hegewald 1986, Lürling \& Beekman 1999, Trainor 1998), even at cell density far above ca. 1000 cells. $\mathrm{ml}^{-1}$. Hence, low cell density (Egan \& Trainor 1989b) does not seem a prerequisite for unicell development in several Desmodesmus and Scenedesmus strains. And why are there that few reports of unicellular Desmodesmus and Scenedesmus from the field? One explanation could be that due to the activity of grazers unicells are produced only in very low numbers, which experience a high mortality ; protective colonies are being induced. Trainor (1979) observed that unicells disappeared when incubated in dialysis sacks in the field or when cultured in pond water in the laboratory. Interestingly, in another study ten years later the same strain produced unicells in water from the same pond (Egan \& Trainor $1989 b, d)$. Perhaps the activity of grazers had been involved in this plasticity and grazer-associated chemical cues might account for the different observations by Trainor (1979) and Egan \& Trainor (1989b,d). Also colonial $D$. abundans from the field formed unicells in the laboratory (Fott 1968). Another reason may be that unicells are simply not recognized as Scenedesmus. Opening a textbook one will find Desmodesmus and Scenedesmus presented as «a freshwater colonial green alga» often supported with images of four-celled coenobia. Unicells may resemble species described in at least eight other green algal genera (Trainor 1998). Kessler and co-workers using sequence analyses of $18 \mathrm{~S}$ rDNA showed that two taxa of the unicellular
Chlorella were in fact unicellular Scenedesmus while one Chlorella and one Kermatia had to be designated to Desmodesmus (Kessler et al. 1997)!

A decade ago, an interesting dialogue took place between Trainor and Egan (1990) and Hegewald and Schmidt (1990) on Lagerheimia hindakii being the unicellular stage of $D$. subspicatus illustrative of the firmly anchored dogma of Desmodesmus and Scenedesmus being colonial. However, an investigation of literature data shows that the phenomenon of unicellular Desmodesmus and Scenedesmus is widespread in both genera (Table 5). Undoubtedly, the species list in table 4 is far from complete, but includes already more than 100 different strains and suggests that unicells may be common in both Desmodesmus and Scenedesmus. Yet environmental conditions determine which phenotypes will be produced. Therefore, analysis of the biological environment in which the organisms are collected could provide essential information on the expressed phenotypic plasticity in laboratory cultures. Moreover, it may provide an explanation for observed variations in closely related organisms to the same cue.

The hypothesized seasonal life-history cycle of Desmodesmus and Scenedesmus (Egan \& Trainor $1989 \mathrm{~b}, \mathrm{~d})$ could involve biological aspects rather than merely abiotic influences. The cyclomorphosis observed in Daphnia was initially correlated to changes in water-temperature (e.g. Jacobs 1961, Brooks 1966),

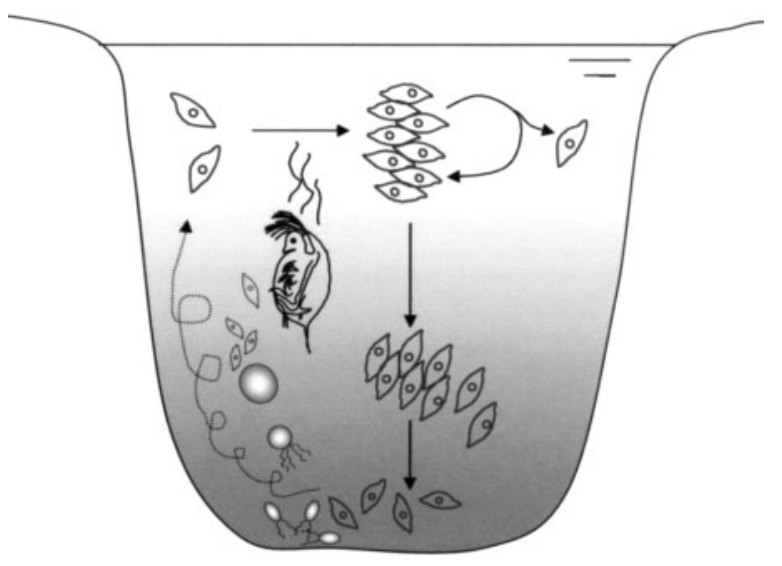

Fig. 7. Hypothesized cycle for Scenedesmus in a lake. To pare down the mortality through grazing, colonies are formed in the presence of grazers, such as Daphnia. These colonies may experience higher sinking losses and could enter deeper water layers and the sediment, where colonies disintegrate and may be resuspended as inocula for subsequent blooms. On the sediment also gametes ( $>$ ) may be formed that could form quadriflagelatte zoospores and grow into large spherical zygotes from which unicells are being released. 
Table 5. Summary of Desmodesmus and Scenedesmus species for which the formation of unicells has been reported.

\begin{tabular}{|c|c|}
\hline Desmodesmus & References \\
\hline D. abundans & Fott (1968), Hegewald \& Schnepf, E. (1991) \\
\hline D. armatus & Swale (1967), Trainor \& Egan (1990), Tukaj \& Bohdanovicz (1995) \\
\hline D. armatus var. longispina & Mur (1971) \\
\hline D. bicellularis & Hegewald (1989) \\
\hline D. communis & Egan \& Trainor (1990) \\
\hline D. intermedius & Hegewald et al. (1998a) \\
\hline D. kissii & Hegewald (1989), Trainor (1995) \\
\hline D. komarekii & Hegewald (1989), Egan \& Trainor (1990) \\
\hline D. lunatus & Hegewald et al. (1998b) \\
\hline D. microspina & Tukaj \& Bohdanovicz (1995) \\
\hline D. opoliensis & Mur (1971) \\
\hline D. quadricauda & Overbeck \& Stange-Bursche (1966), Steenbergen (1978), Lürling \& \\
\hline & Beekman (1999) \\
\hline D. subspicatus & Hessen \& Van Donk (1993), Trainor (1993), Lürling (1999) \\
\hline Scenedesmus & References \\
\hline S. acuminatus & Krienitz (1987), Hegewald (1989), Mladenov \& Furnadžieva (1995) \\
\hline S. acutiformis & Hegewald $(1982,1989)$ \\
\hline S. acutus & Krienitz (1987), Nagy-Tóth et al. (1992) \\
\hline S. acutus f. alternans & Krienitz (1987) \\
\hline S. acutus f. costulatus & Krienitz (1987) \\
\hline S. falcatus & Krienitz (1987), Mladenov \& Furnadžieva (1995) \\
\hline S. obliquus & Hegewald (1982), Holtmann \& Hegewald (1986), Wasmund (1992) \\
\hline S. obtusiusculus & Kylin \& Das (1967), Monahan (1977), Krienitz (1987) \\
\hline S. pectinatus & Holtmann \& Hegewald (1986) \\
\hline S. pseudobernardii & Krienitz (1987) \\
\hline S. regularis & Hegewald et al. (2001) \\
\hline
\end{tabular}

but later predator kairomones appeared the causal factor (e.g. Hebert \& Grewe 1985, Dodson 1988, Tollrian 1990, 1994). In Desmodesmus and Scenedesmus, among many factors, grazer kairomones may trigger the formation of eight-celled colonies that experience high sinking rates. Once colonies enter deeper water layers prolonged periods in darkness undoubtedly will result in colony disintegration, which could enhance the chance of being moved to upper water layers (Fig. 7). When Scenedesmus enters the top layer of the sediment colony disintegration together with the capa- bility of surviving prolonged periods of darkness results in unicells that, after resuspension, may serve as inocula for subsequent blooms (Dehning \& Tilzer 1989, Egan \& Trainor 1989b,d). The sedimented algae form a thin surficial film of deposited material (Bengtsson \& Hellström 1992), with a high proportion of algae and total biomass that could exceed the water column concentration by one or two orders of magnitude (Carrick et al. 1993). This means that with low temperature, low light, high algal densities and perhaps no excess of nitrogen the prerequisites for game- 
te production could be fulfilled. Gametes and zygotes are flagellated and could contribute to the recruitment of Desmodesmus and Scenedesmus to the water column. The organisms released from the zygote appeared always unicells (Trainor 1998). Hypothesising that sexual reproduction is a characteristic of all Desmodesmus and Scenedesmus, all members of both genera may eventually be capable of the formation of unicells as has already been suggested by Trainor (1998).

\section{Morphological variability in other phytoplank- ton organisms}

Phenotypic plasticity is not restricted to the Scenedesmaceae, but has been reported in many phytoplankton species, such as Chrysophytes (Sandgren 1988), green algae, cyanobacteria and diatoms (Trainor et al. 1971). In the dinophyte Ceratium variation in spine length and number of spines has been observed (Hutchinson 1967), but it is unclear if grazers could be of any influence. Filamentous cyanobacteria have been reported to appear as flakes in the presence of Daphnia but as single filaments in their absence (Lynch 1980, Holm et al. 1983). Yet, chemical cues from Daphnia appeared ineffective in inducing flakes in Oscillatoria agardhii and Aphanizomenon flos-aqua (Lürling 1999a). Similarly, chemicals released from Daphnia ambigua (Fulton III \& Paerl 1987) or D. magna (Hessen \& Van Donk 1993) appeared ineffective as colonyinducing agents in the cyanobacterium Microcystis aeruginosa. However, in three strains of $M$. aeruginosa the addition of Daphnia water resulted in significantly increased mean particle volumes (Lürling 1999a). Protozoan grazers caused a unicellular Chlorella culture to change into one dominated by eight-celled colonies (Boraas et al. 1998), whereas Chlamydomonas formed palmelloids in the presence of herbivorous zooplankton (Mikheeva and Kruchkova 1980). Hence, the presence of grazers has been reported to co-occur repeatedly with altered morphologies in phytoplankton, but chemical cues from grazers being among the most important causal factors is not strongly supported so far. Nonetheless, the phenomenon of Daphnia-induced colony formation seems not restricted to the genera Desmodesmus (Hessen \& Van Donk 1993) and Scenedesmus (Lampert et al. 1994, Lürling 1998). Colonies were also formed when Coelastrum (Lürling 1999a, Van Donk et al. 1999) or Actinastrum (Yasumoto et al. 2000) were exposed to chemical cues released from Daphnia. These chemical cues alter the chemical environment, but it is the sum of all environmental factors operating which determines the environment and thereby the phenotypes that will be produced and are sub- jected to selection. The major selective forces are competition and predation and it could be postulated that different sets of environmental conditions (e.g. nutrients, light, temperature, and predation) could yield various morphologies. Research on phenotypic plasticity in algae would then benefit from the usage of different sets of environmental conditions (including both abiotic and biotic factors) and could eventually resolve which morphologies are produced under specific conditions. Many Desmodesmus and Scenedesmus appear almost always to be colonial, while numerous others may be mainly unicellular. It is challenging to classify the colonial ones as being protected and the unicells as being competitively superior and thus a worthwhile focus could be testing the hypothesis of a trade-off between competitively advantageous traits and defensive traits.

\section{Summarising}

Desmodesmus and Scenedesmus are characterised by a high degree of phenotypic plasticity, although strongly different among various strains. They are cosmopolitans and able to withstand harsh conditions, su$\mathrm{ch}$ as periods with strong grazing pressure. Under those conditions typical phenotypes, protective eight-celled colonies, could be produced. This induced defence is observed in many non-spiny Scenedesmus and some spiny Desmodesmus. The eight-celled colonies can be induced by herbivorous zooplankton chemical cues, but not by carnivorous zooplankton or fish ; hence, not by more general animal excretory products. The grazing activity of small sized grazers is reduced, but not of large Daphnia. Nonetheless, grazing protection of colonial Scenedesmus is probably more efficient under natural than under carbon/light limited laboratory conditions. As a result of the induction, colonies may experience higher sinking rates and even could disappear from the euphotic zone. Once entered deeper water layers colonies may disintegrate into unicells and on the sediment sexual reproduction is hypothesised to occur both enhancing the chance of resuspension and re-colonisation of the water column.

Phenotypic plasticity may be more widespread among algae than often assumed; perhaps numerous organisms may produce several morphologies when subjected to different sets of environmental conditions.

\section{Acknowledgement}

ML was supported by a fellowship from the Royal Netherlands Academy of Arts and Sciences. 


\section{References}

An S.S., Friedl T. \& Hegewald E. 1999. - Phylogenetic relationships of Scenedesmus and Scenedesmus-like coccoid green algae as inferred from ITS-2 rDNA sequence comparisons. Plant Biol., $1,418-429$.

Bengtsson L. \& Hellström T. 1992. - Wind-induced resuspension in a small shallow lake. Hydrobiologia, 241, 163-172.

Belkinova D. \& Mladenov R. 2002. - Morphological variability in clonal cultures of Scenedesmus nygaardii Hub.-Pest. And Scenedesmus bernardii G.M. Smith (Chlorophyta). Algol. Stud., 104, 123-128.

Boraas M.E., Seale D.B. \& Boxhorn J.E. 1998. — Phagotrophy by a flagellate selects for colonial prey : a possible origin of multicellularity. Evol. Ecol., 12, 153-164.

Brooks J. 1966. - Cyclomorphosis, turbulence and overwintering in Daphnia. Verh. int. Ver. Limnol., 16, 1653-1659.

Burns C.W. 1968. - The relationship between body size of filterfeeding Cladocera and the maximum size of particles ingested. Limnol. Oceaonogr., 13, 675-678.

Cain J.R. \& Trainor F.R. 1976. - Regulation of gametogenesis in Scenedesmus obliquus. J. Phycol., 12, 383-390.

Canter-Lund H. \& Lund J.W.G. 1995. - Freshwater Algae. Their microscopic world explored. Biopress Ltd., Bristol, $360 \mathrm{pp}$

Carrick H.J., Aldridge F.J. \& Schelske C.L. 1993. - Wind influences phytoplankton biomass and composition in a shallow, productive lake. Limnol. Oceanogr., 38, 1179-1192.

Chodat R. 1926. - Scenedesmus étude de génétique, de systématique expérimentale et d'hydrobiologie. Rev. Hydrobiol., 3, $71-258$

Conway K. \& Trainor F.R. 1972. - Scenedesmus morphology and floatation. J. Phycol., 8, 138-143.

Corradi M.G., Gorbi G. \& Bassi M. 1995. — Hexavalent Chromium induces gametogenesis in the freshwater alga Scenedesmus асиtus. Ecotoxicol. Environ. Saf., 30, 106-110.

Dehning I. \& Tilzer M.M. 1989. - Survival of Scenedesmus acuminatus (Chlorophyceae) in darkness. J. Phycol., 25, 509-515.

DeLange H.J. \& Van Donk E. 1997. — Effects of UVB-irradiated algae on life history traits of Daphnia pulex. Freshwater Biol., 38, 711-720.

Dodson S.I. 1988. - Cyclomorphosis in Daphnia galeata mendotea Birge and daphnia retrocurva Forbes as a predator-induced response. Freshw. Biol., 19, 109-114.

Egan P.F. \& Trainor F.R. 1989a. — Gamete production in Scenedesmus armatus (Chod.) Chod. J. Phycol., 25, 15.

Egan P.F. \& Trainor F.R. 1989b. — Low cell density : the unifying principle for unicell development in Scenedesmus (Chlorophyceae). Br. Phycol. J., 24, 271-283.

Egan P.F. \& Trainor F.R. 1989c. - The effect of media and inoculum size on the growth and morphological development of Scenedesmus communis Hegew. (Chlorophyceae) in culture. Arch. Hydrobiol., 117, 77-95.

Egan P.F. \& Trainor F.R. 1989d. - The role of unicells in the polymorphic Scenedesmus armatus. J. Phycol., 25, 65-70.

Egan P.F. \& Trainor F.R. 1990. - Phenotypic plasticity in Scenedesmus communis (Chlorophyceae). I. Relationship of S. communis to S. komarekii. J. Phycol., 26, 367-376.

Egan P.F. \& Trainor F.R. 1991. - Phenotypic plasticity in Scenedesmus communis (Chlorophyceae). II. Examples of algal cycloand noncyclomorphosis. Am. J. Bot., 78, 37-52.

Fott B. 1968. - Chodatella stages in Scenedesmus. Acta Univ. Carol. Biol., 1967, 189-196.

Franck A. 1995. - Daphniainducierte Coenobienbildung bei Scenedesmus acutus : physiologische und biochemische Aspekte. Diplomarbeit, Fachochschule Lübeck (In German).
Fulton III R.S. \& Paerl H.W. 2000. - Effects of colonial morphology on zooplankton utilization of algal resources during blue-green algal (Microcystis aeruginosa) blooms. Limnol. Oceanogr., 32, 634-644.

Goldman J.C., Porcella D.B., Middlebrooks E.J. \& Toerien D.F. 1972. - The effects of carbon on algal growth. Wat. Res., 6, 637-679.

Goldman J.C., Oswald W.J. \& Jenkins D. 1974. — The kinetics of inorganic carbon limited algal growth. J. WPCF, 46, 554-574.

Goldman J.C., McCarthy J.J. \& Peavey D.G. 1979. — Growth rate influence on the chemical composition of phytoplankton in oceanic waters. Nature, 279, 310-315.

Goulder R. 1972. - Grazing by the ciliated protozoon Loxodus magnus on the alga Scenedesmus in a eutrophic pond. Oikos, 23, 109-115.

Grover J.P. 1989. — Effects of Si : P supply ratio, supply variability, and selective grazing in the plankton : :An experiment with natural algal and protistan assemblage. Limnol. Ocenanogr., 34 349-367.

Gurevitch J., Morrison J.A. \& Hedges L.V. 2000. — The interaction between competition and predation : a meta-analysis of field experiments. Am. Nat., 155, 435-453.

Hebert P.D.N. \& Grewe P.M. 1985. — Chaoborus-induced shifts in the morphology of Daphnia ambigua. Limnol. Oceanogr., 30 , 1291-1297.

Hegewald E. 1978. — Eine neue Unterteilung der Gattung Scenedesmus Meyen. Nova Hedwigia, 30, 343-376.

Hegewald E. 1982. - Taxonomic-morphological studies of Scenedesmus isolates from culture collections. Algol. Stud., 29, 375-406.

Hegewald E. 1989. - The Scenedesmus strains of the culture collection of the university of Texas at Austin (UTEX). Algol. Stud., 55, 153-189.

Hegewald E. 2000. — New combinations in the genus Desmodesmus (Chlorophyceae, Scenedesmaceae). Algol. Stud., 96, 1-18.

Hegewald E. \& Silva P. 1988. — An annotated catalogue of Scenedesmus and nomenclaturally related genera including original descriptions and figures. Bibl. Phycol., 80, 1-587.

Hegewald E. \& Schmidt A. 1991. _ Lagerheimia hindakii is not the unicellular stage of Scenedesmus. J. Phycol., 27, 555.

Hegewald E. \& Schnepf E. 1991. - Scenedesmus abundans (Kirchn.) Chod., an older name for Chlorella fusca Shih. Et Krauss. Arch. Protistenkd., 139, 133-176.

Hegewald E., An S.S. \& Tsarenko P. 1998a. - Revision of Scenedesmus intermedius Chod. (Chlorophyta, Chlorococcales). Algol. Stud., 88, 67-104.

Hegewald E., An S.S., Schnepf E. \& Tsarenko P. 1998b. — Taxonomy and cell wall ultrastructure of Scenedesmus lunatus (Chlorophyta, Chlorococcales). Algol. Stud., 91, 11-25.

Hegewald E., Stojkovic-Tadic S., Belkinova D. \& Mladenov R. 2001. - Scenedesmus regularis Svir. (Chlorophyta, Chlorophyceae), its taxonomy and salt stress response. Algol. Stud., 102, 147-159.

Hessen D.O. \& Van Donk E. 1993. - Morphological changes in Scenedesmus induced by substances released from Daphnia. Arch. Hydrobiol., 127, 129-140.

Holm N.P., Ganf G.G. \& Shapiro J. 1983. — Feeding and assimilation rates of Daphnia pulex fed Aphanizomenon flos-aqua. Limnol. Oceanogr., 28, 677-687.

Holtmann T. \& Hegewald E. 1986. — The influence of nutrient solutions on the variability of the genus Scenedesmus subgenus Acutodesmus. Algol. Stud., 44, 365-380. 
Horn W. 1981. - Phytoplankton losses due to zooplankton grazing in a drinking water reservoir. Int. Revue Ges. Hydrobiol., 66, 787-810.

Hutchinson G.E. 1967. — A Treatise on Limnology. II. Introduction to Lake Biology and the limnoplankton. John Wiley \& Sons, New York. 1115 pp.

Jacobs J. 1961. - Cyclomorphosis in Daphnia galeata mendotae Birge, a case of environmentally controlled allometry. Arch. Hydrobiol., 58, 7-71.

Kessler E., Schäfer M., Hümmer C., Kloboucek A. \& Huss V.A.R. 1997. - Physiological, biochemical, and molecular characters for the taxonomy of the subgenera of Scenedesmus (Chlorococcales, Chlorophyta). Bot. Acta, 110, 244-250.

Krienitz K. 1987. - Studies to the morphology and taxonomy of the subgenus Acutodesmus (Chlorellales). Algolog. Stud., 46, 1-37.

Kylin A. \& Das G. 1967. - Calcium and strontium as micronutrients and morphogenetic factors for Scenedesmus. Phycologia, 6, 201-210.

Lampert W., Rothhaupt K.O. \& von Elert E. 1994. — Chemical induction of colony formation in a green alga (Scenedesmus acutus) by grazers (Daphnia). Limnol. Oceanogr., 39, 1543-1550.

Levitan C. 1987. - Formal stability analysis of a planktonic freshwater community. Pages 71-100 in Kerfoot W.C. \& Sih A. (eds) Predation. Direct and indirect impacts on aquatic communities. Univ. Press of New England.

Lukavský J. 1991. - Motile cells in Scenedesmus obliquus in outdoor mass culture. Arch. Protistenkd., 140, 345-348.

Lukavský J. \& Cepák V. 1998. - Motile cells in outdoor mass culture of Scenedesmus obliquus II. Algol. Stud., 91, 101-108.

Lürling M. 1998. — Effect of grazing-associated infochemicals on growth and morphological development in Scenedesmus acutus Meyen (Chlorophyceae). J. Phycol., 34, 578-586.

Lürling M. 1999a. - The smell of water. Grazer-induced colony formation in Scenedesmus. Wageningen University, ISBN 905808-046-3, 270 pp.

Lürling M. 1999b. - Grazer-induced coenabial formation in clonal cultures of Scenedesmus obliquus (Chlorococcales, Chlorophyceae). J. Phycol., 35, 19-23.

Lürling M. Submitted. - The effect of substances from different zooplankton species and fish on the induction of defensive morphology in the green alga Scenedesmus. J. Plankton Res.

Lürling M. \& Beekman W. 1999. - Grazer-induced defenses in Scenedesmus (Chlorococcales ; Chlorophyceae) : coenobium and spine formation. Phycologia, 38, 368-376.

Lürling M. \& Van Donk E. 1996. — Zooplankton-induced unicellcolony transformation in Scenedesmus acutus and its effect on growth of herbivore Daphnia. Oecologia, 108, 432-437.

Lürling M. \& Van Donk E. 1997a. - Morphological changes in Scenedesmus induced by infochemicals released in situ from zooplankton grazers. Limnol. Oceanogr., 42, 783-788.

Lürling M. \& Van Donk E. 1997b. — Life history consequences for Daphnia pulex feeding on nutrient limited phytoplankton. Freshwater Biol., 38, 693-709.

Lürling M. \& Van Donk E. 1999. — Grazer-induced colony formation in Scenedesmus acutus Meyen (Chlorophyceae), Ecomorph expression at different temperatures. J. Phycol., 35, 1120-1126

Lürling M. \& Van Donk E. 2000. — Grazer-induced colony formation in Scenedesmus : Costs of being colonial ? Oikos, 88, 111-118.

Lürling M., De Lange H.J.\& Van Donk E. 1997. — Changes in food quality of the green alga Scenedesmus induced by Daphnia infochemicals : biochemical composition and morphology. Freshwater Biol., 38, 619-628.
Lürling M., Van Donk E. \& Beekman-Lukassen W. 2000. — Algal concentration affects grazer-induced colony formation in Scenedesmus obliquus (Turpin) Kützing (Chlorophyceae). Verh. Internat. Verein. Limnol., 27, 2124-2127.

Lynch M. 1980. - Aphanizomenon blooms : Alternate control and cultivation by Daphnia pulex. Pages 299-304 in Kerfoot W.C. (ed). Evolution and ecology of zooplankton communities. University Press of New England, Hanover.

Massalski A., Trainor F.R. \&. Shubert. E. 1971. — Wall ultrastructure of Scenedesmus culture N46. Arch. Microbiol., 96, 145-153.

Mikheeva T.M. \& Kruchkova H.M. 1980. - Morphological changes in Chlamydomonas sp and Scenedesmus acuminatus in the presence of zooplankton. Botanica, 5, 60-63.

Mladenov R. \& Belkinova D. 1997. - Variability of Scenedesmus acuminatus (Lagerh.) Chod. and Scenedesmus pectinatus Meyen in nutrient solutions with different $\mathrm{NaCl}$ concentrations. Arch. Protistenkd., 147, 393-399.

Mladenov R. \& Furnadzieva S. 1995. - Morphological variability of the clonal cultures of Scenedesmus falcatus Chod. and Scenedesmus acuminatus (Lagerh.) Chod.) Algolog. Stud., 79, 93-107.

Mladenov R. \& Furnadzieva S. 1999. - Ontogenetic changes in clonal cultures of Scenedesmus acuminatus (Lagerh.) Chod. and Scenedesmus pectinatus Meyen. Algol. Stud., 92, 35-46.

Monahan T. 1977. - Effects of organic phosphate on the growth and morphology of Scenedesmus obtusiusculus (Chlorophyceae). Phycologia, 16, 133-137.

Mur L.R. 1971. - Scenedesmus in brak water (in Dutch) PhD thesis, University of Amsterdam 167 pp.

Nagy-tóth F., Péterfi L.I. \& Fodorpataki L. 1992. — Effects of carbon sources on the morphology and structure of Scenedesmus acutus Meyen. Acta Bot. Hung., 37, 295-316.

Nilshammar M. \& Walles B. 1974. — Electron microscope studies on cell differentiation in synchronized cultures of the green alga Scenedesmus. Protoplasma, 79, 317-332.

Overbeck J. \& Stange-Bursche M.-E. 1966. — Experimentelle Untersuchungen zum Coenobienform wechsel von Scenedesmus quadricauda (Turp.) Bréb. Ber. Deutsch. Bot. Ges., 78, 357-372.

Porter K.G. 1977. — The plant-animal interface in freshwater ecosystems. Am. Sci., 65, 159-170.

Ramos-Cárdenas A. \& de Lara-Isassi G. 1985. — The effect of nutrients in the development of algal populations (Scenedesmus spp.). Arch. Hydrobiol.Beih. Ergebn. Limnol., 20, 63-69.

Sandgren C.D. 1988. - The ecology of chrysophyte flagellates : their growth and perennation strategies as freshwater phytoplankton. in Sandgren C.D. (ed). Growth and reproductive strategies of freshwater phytoplankton. Cambridge University Press, Cambridge, pp 442.

Schindler D.W. 1971. - Carbon, nitrogen and phosphorus and the eutrophication of freshwater lakes. J. Phycol., 7, 321-329.

Schindler D.W., Brunskill G.J. \& Emerson S. 1972. — Atmospheric carbon dioxide : its role in maintaining phytoplankton standing crops. Science, 177, 1192-1194.

Senger H. \& Fleischhacker P. 1978. - Adaptation of the photosynthetic apparatus of Scenedesmus obliquus to strong and weak light conditions. I. Differences in pigments, photosynthetic capacity, quantum yield and dark reactions. Physiol. Plant., 43, 35-42.

Siver P. \& Trainor F.R. 1981. - Morphological control and physiology of Scenedesmus strain 170. Phycologia, 20, 1-11

Skulberg O.M. \& Skulberg R. 1990. - Research with algal cultures. NIVA's culture collection of algae. NIVA-report ISBN 82-551743-6.

Smith G.M. 1914. - The cell structure and colony formation in Scenedesmus. Arch. Protistenkd., 32, 278-297. 
Smith G.M. 1916. - A monograph of the algal genus Scenedesmus based upon pure culture studies. Trans. Wisc. Acad. Sci., 18, $422-530$.

Steenbergen C.L.M. 1978. - Pleomorphism of Scenedesmus quadricauda (Turp.) Bréb. (Chlorophyceae) in synchronized cultures. Mitt. Int. Verein. Limnol., 21, 216-223.

Sterner R.W. 1993. - Daphnia growth on varying quality of Scenedesmus : mineral limitation of zooplankton. Ecology, 74, 2351-2360.

Sterner R.W., Hagemeier D.D., Smith R.F. \& Smith W.L. 1993. Phytoplankton nutrient limitation and food quality for Daphnia. Limnol. Oceanogr., 38, 857-871.

Swale E.M.F. 1967. - A clone of Scenedesmus with Chodatellastages. Br. phycol. Bull., 3, 281-293.

Tollrian R. 1990. — Predator-induced helmet formation in Daphnia cucullata (Sars). Arch. Hydrobiol., 119, 191-196.

Tollrian R. 1994. - Fish-kairomone induced morphological changes in Daphnia lumholtzi (Sars). Arch. Hydrobiol., 130, 69-75.

Trainor F.R. 1963. - Zoospores in Scenedesmus obliquus. Science, 142, 1673-1674.

Trainor F.R. 1964. - The effect of composition of the medium on morphology in Scenedesmus obliquus. Can. J. Bot., 42, 515-518.

Trainor F.R. 1965. - Motility in Scenedesmus cultures incubated in nature. Bull. Torrey Bot. Club, 92, 329-332.

Trainor F.R. 1969. - Scenedesmus morphogenesis. Trace elements and spine formation. J. Phycol., 5, 185-190.

Trainor F.R. 1979. - Scenedesmus AP 1 (Chlorophyceae) : polymorphic in the laboratory but not in the field. Phycologia, 18, 273-277.

Trainor F.R. 1993a. - Gametes in Scenedesmus armatus (Chlorophyceae). Algol. Stud., 70, 39-49.

Trainor F.R. 1993b. - Cyclomorphosis in Scenedesmus subspicatus R. Chod. Cell behaviour during the unicell-colony transformation of a phenotypicly plastic organism. Arch. Protistenkd., 143 55-61.

Trainor F.R. 1998. - Biological aspects of Scenedesmus (Chlorophyceae)-phenotypic plasticity. Nova Hedwigia, Beiheft, 117, $367 \mathrm{pp}$.

Trainor F.R. \& Burg C. 1965a. - Motility in Scenedesmus dimorphus, Scenedesmus obliquus, and Coelastrum microporum. J. Phycol., 1, 15-18.

Trainor F.R. \& Burg C. 1965b. - Scenedesmus obliquus sexuality. Science, 142, 1094-1095.

Trainor F.R. \& Burg C. 1965c. - Detection of bristles in Scenedesmus species. J. Phycol., 1, 139-144.

Trainor F.R. \& Egan P.F. 1988. - The role of bristles in the distribution of a Scenedesmus (Chlorophyceae). Br. Phycol. J., 23, 135-141.

Trainor F.R. \& Roskosky F.G. 1967. - Control of unicell formation in a soil Scenedesmus. Can. J. Bot., 45, 1657-1664.

Trainor F.R. \& Rowland H.L. 1968. - Control of colony and unicell formation in a Scenedesmus. J. Phycol., 4, 310-317.
Trainor F.R., Cain J.R. \& Shubert E.L. 1976. — Morphology and nutrition of the colonial green alga Scenedesmus : 80 years later. Bot. Rev., 42, 5-25.

Trainor F.R., Rowland H.L., Lylis J.C., Winter P.A. \& Bonanomi P.L. 1971. - Some examples of polymorphism in algae. Phycologia, 10, 113-119.

Tukaj Z \& Bohdanowicz J. 1995. — Diesel-fuel oil indiced morphological changes in Scenedesmus species (Chlorococcales). Algol. Stud., 77, 83-94.

Tukaj Z., Kubinova A. \& Zachleder V. 1996. — Effect of irradiance on growth and reproductive processes during the cell cycle in $\mathrm{Sce}$ nedesmus armatus (Chlorophyta). J. Phycol., 32, 624-631.

Turpin P. 1828. - Aperçu organographique sur le nombre deux, considéré comme multiplicateur de quatre, huit, douze, seize, trente-deux et soixante-quatre dans la structure des végétaux d'un ordre inférieur. Mémoires du Muséum National d'Histoire Naturelle Paris, 16, 295-344.

Uherkovich G. 1966. - Die Scenedesmus-Arten Ungarns. Akadémiai Kiadó, Budapest, 173 pp.

Van den Hoek C., Mann D.G. \& Jahns H.M. 1995. — Alga : an introduction to phycology. Cambridge University Press, Cambridge, $623 \mathrm{pp}$.

Van Donk E., Lürling M. \& Lampert W. 1999. — Consumer-induced changes in phytoplankton : inducibility, costs, benefits and impacts on grazers. Pages 89-103 in Tollrian R. \& Harvell C.D. (eds). The ecology and evolution of inducible defenses. Princeton University Press, New Jersey.

Van Hannen E.J., Lürling M. \& Van Donk E. 2000. - Sequence analysis of the ITS2 region : a tool to identify strains of Scenedesmus. J. Phycol., 36, 605-607.

Van Hannen E.J., Fink P. \& Lürling M. 2002. — A revised secondary structure model for the internal transcribed spacer 2 of the green algae Scenedesmus and Desmodesmus and its implication for the phylogeny of these algae. Eur. J. Phycol., 37, 203-208.

Visser P.M., Massault L., Huisman J. \& Mur L.R. 1996. — Sedimentation losses of Scenedesmus in relation to mixing depth. Arch. Hydrobiol., 136, 289-308.

Von Elert E. \& Franck A. 1999. - Colony formation in Scenedesmus : grazer-mediated release and chemical feature of the infochemical. J. Plankton Res., 21, 789-804.

Wasmund N. 1992. - Temperature and salinity demand of Scenedesmus abundans (Kirchn.) Chod. and Scenedesmus obliquus (Turp.) Kütz. (Chlorophyceae). Limnologica, 22, 249-263.

West-Eberhard M. 1989. - Phenotypic plasticity and the origins of diversity. Ann. Rev. Ecol. Syst., 20, 249-278.

Wiltshire K.H. \& Lampert W. 1999. - Urea excretion by Daphnia : A colony-inducing factor in Scenedesmus? Limnol. Oceanogr., 44, 1894-1903.

Yasumoto M., Ooi T., Takenori K. \& Kasai F. 2000. — Characterization of Daphnia kairomone inducing morphological change of green alga Actinastrum sp. Tennen Yuki Kagobutsu Toronkai Keon Yoshishu, 42, 385-390. (In Japanese) 